\title{
BAMBI wt Allele
}

National Cancer Institute

\section{Source}

National Cancer Institute. BAMBI wt Allele. NCI Thesaurus. Code C54368.

Human BAMBI wild type allele is located within 10p12.3-p11.2 and is approximately $6 \mathrm{~kb}$ in length. This allele, which encodes BMP and activin membrane-bound inhibitor homolog protein, may play a role in the attenuation of transforming growth factor-beta signaling. 